\title{
Milk production, nitrogen balance, and fiber digestibility prediction of corn, whole plant grain sorghum, and forage sorghum silages in the dairy cow
}

\author{
S. Colombini, G. Galassi, G. M. Crovetto, and L. Rapetti ${ }^{1}$ \\ Università degli Studi di Milano, Dipartimento di Scienze Agrarie e Ambientali, via Celoria 2, 20133, Milano, Italy
}

\begin{abstract}
Total mixed rations containing corn (CS), whole plant grain sorghum (WPGS), or forage sorghum (FS) silages were fed to 6 primiparous Italian Friesian cows to determine the effects on lactation performance, nutrient digestibility, and $\mathrm{N}$ balance. Furthermore, the relationship between in vivo total-tract neutral detergent fiber (NDF) digestibility (ttNDFD) and the ttNDFD derived by the Cornell Net Carbohydrate and Protein System (CNCPS) model was assessed. Cows were assigned to 1 of 3 diets in a replicated $3 \times 3$ Latin square with 28-d periods. The experimental treatment was silage type and 3 different silages were included in the diets. The diets were formulated to be iso-NDF. Accordingly, each diet was formulated to contain $41.5 \%$ CS silage, $36.7 \%$ WPGS silage, or $28.0 \%$ FS silage, on a DM basis. Starch content was balanced by adding the appropriate amount of corn meal. Separate collection of total urine and feces was performed. Dietary forages were analyzed for in vitro NDF digestibility ( 6 and $24 \mathrm{~h}$ of incubation) to predict fiber digestion rate with $2 \mathrm{NDF}$ pools (digestible and indigestible). Rumen digestibility of the potentially digestible NDF pool was predicted using CNCPS version 6.1, using the in vitro forage fiber digestion rate. The ttNDFD was predicted assuming that intestinal digestibility of the NDF amount escaping rumen digestion was 20\%, according to the CNCPS model. Dry matter intake was decreased by approximately $1.8 \mathrm{~kg} / \mathrm{d}$ in cows fed the FS diet compared with the other diets, probably for the greater particle size of FS diet. Hence, milk yield $(\mathrm{kg} / \mathrm{d})$ was lowest for FS (23.6), intermediate for WPGS (24.6), and highest for the CS diet (25.4). Milk urea N (mg/dL) was highest for FS (12.9), intermediate for WPGS (11.9), and lowest for CS (10.7) diet. In vivo ttNDFD (\%) was 51.4 (CS), 48.6 (WPGS), and 54.1 (FS); this was probably due to a higher retention time of FS diet in the rumen rather than to a better quality of the FS silage, as confirmed by in situ and in vitro results. Urinary
\end{abstract}

Received April 13, 2011.

Accepted April 2, 2012.

${ }^{1}$ Corresponding author: luca.rapetti@unimi.it
$\mathrm{N}$ excretion (\% N intake) was highest for FS (31.8), intermediate for WPGS (29.3), and lowest for the CS (27.5) diet. The predicted ttNDFD $(37.7,36.3$, and $39.5 \%$ for CS, WPGS, and FS, respectively) were lower than the in vivo results. Providing an adequate starch supplementation, whole plant grain sorghum silage can replace corn silage in dairy cows TMR. Forage sorghum silage had rumen NDF digestibility comparable to the other silages; however, it had a negative effect on dry matter intake and milk production, probably due to an inadequate effect of processing.

Key words: sorghum silage, $\mathrm{N}$ balance, neutral detergent fiber digestibility, Cornell Net Carbohydrate and Protein System

\section{INTRODUCTION}

Corn silage (CS) is the main forage fed to dairy cows in the Po Plain (Italy) due to its high DM yield, high $\mathrm{NE}_{\mathrm{L}}$ concentration, high potential intake, and optimum DM content at harvest. However, large amounts of $\mathrm{N}$ fertilizers and water are needed to achieve satisfactory yields, thus increasing the crop production costs and reducing the agricultural sustainability. Furthermore, in the European Union, the negative relationship between animal density and water quality led to a precautionary application threshold of $170 \mathrm{~kg}$ of manure $\mathrm{N}$ per hectare per year to protect water quality in the most vulnerable zones (European Commission, 1991). Nitrogen concentrations in ground and surface waters are determined by the combination of manure and $\mathrm{N}$ fertilizer; thus, the use of a low-N input crop is advisable. Sorghum is a crop with high biomass yield, low $\mathrm{N}$ fertilizer and water inputs, and good $\mathrm{N}$ efficiency (Gardner et al., 1994); therefore, it could be a valuable alternative to corn.

Another potential advantage of sorghum silage is the adequate rumen NDF digestibility (NDFD). Spanghero et al. (2009) reported an average in vitro NDFD of $48.9 \%$ for CS samples collected over $3 \mathrm{yr}$ in the Po Plain; this value is close to the NDFD values reported by Sanderson (1993) for grain sorghum silage samples. Di Marco et al. (2009) found a wide range for in vitro NDFD (48 h) of forage sorghum (FS) silages (from 49.2 
to $63.8 \%$ ) and the in vitro NDFD did not accurately predict the in vivo values. Fiber digestibility depends on potentially digestible NDF (pdNDF) and its rates of digestion $\left(\mathbf{k}_{\mathbf{d}}\right)$ and passage $\left(\mathbf{k}_{\mathbf{p}}\right)$; hence, accurate and precise predictions of the digestion kinetic parameters are important. Van Amburgh et al. (2003) proposed a mathematical approach to predict the pdNDF rumen $k_{d}$ based on NDFD values determined at different times of incubation by an in vitro assay on CS samples. Therefore, the pdNDF $\mathrm{k}_{\mathrm{d}}$ might be used within the Cornell Net Carbohydrate and Protein System (CNCPS) model (Fox et al., 2004; Tylutki et al., 2008) to estimate NDF total-tract apparent digestibility (ttNDFD) assuming that the intestinal digestibility of the NDF amount escaping rumen digestion is 20\% (Sniffen et al. 1992).

Several in vivo studies compared lactation performance and nutrients digestibility on dairy cows fed sorghum or CS diets (among these, Grant et al., 1995; Aydin et al., 1999; Oliver et al., 2004; Miron et al., 2007; Dann et al., 2008); however, in these studies, N-excretion was not determined. A previous research conducted in the Po Plain area (Colombini et al., 2010) showed that milk urea content was higher for cows fed a brown midrib (BMR) sorghum forage in comparison with CS, suggesting probably better $\mathrm{N}$ utilization at rumen level for the CS diet.

The objectives of this study were to (1) compare the effects of diets based on corn, whole plant grain sorghum (WPGS; Sorghum bicolor L.), or FS (Sorghum bicolor $\times$ sorghum-sudangrass) silages on milk yield, nutrient digestibility, and $\mathrm{N}$ balance in dairy cows; and (2) determine the relationship between in vivo ttNDFD and the ttNDFD derived by the CNCPS model (v 6.1) using the $\mathrm{k}_{\mathrm{d}}$ values determined in vitro for the forages of the diets.

\section{MATERIALS AND METHODS}

\section{In Vivo Trial}

Corn (hybrid Agrister; Limagrain Italy, Busseto, Parma, Italy), grain sorghum (Sorghum bicolor hybrid Silo 8416; Syngenta Seed Italy, Milano, Italy), and FS [Sorghum bicolor $\times$ sorghum-sudangrass hybrid Sweet Creek; Società Italiana Veterinaria Agricola Milano SpA (SIVAM), Casalpusterlengo, Lodi, Italy] were sown in adjacent fields in the Po Plain Valley on June 8, 2005. Corn and WPGS forages were harvested on October 4. The second cut of FS was used in the trial and it was harvested on September 23 and field-wilted for $72 \mathrm{~h}$. Whole plant corn was ensiled in bunker silos, whereas WPGS and FS were ensiled in silo tube bags.
Six lactating primiparous Italian Friesian cows with mean BW of $600 \mathrm{~kg}( \pm 41), 178$ DIM $( \pm 13)$ and producing, on average, $28.4 \mathrm{~kg}$ of milk/d $( \pm 2.57)$ at the start of the trial were used. Three diets with a different silage basis were tested: CS, WPGS, or FS. Diets were formulated using the CNCPS model version 5 (Fox et al., $2004)$ and balanced to have a content (\% DM) of 11.0, 36.0 , and 26.0 of MP, NDF, and starch, respectively. Because of the different fiber and starch contents, the 3 forages were included in the experimental diets in different proportions, as well as the corn meal necessary to compensate for the low starch content of the WPGS and FS silages.

The cows were fed the experimental diets in a $3 \times$ 3 repeated Latin square design and each cow was fed the 3 diets in 3 consecutive periods of $28 \mathrm{~d}$ : $21 \mathrm{~d}$ of adaptation and $7 \mathrm{~d}$ of sample collection and data registration. Animals on trials were handled as outlined by the guidelines of the Italian law about animal welfare on experimental animals (Italian Ministry of Health, 1992). During the adaptation periods, cows were housed in tie-stalls and during the sample collection periods, cows were moved to individual metabolic stalls to allow urine and feces collection. Each metabolic chamber contained a $2.5 \times 1.5-\mathrm{m}$ stanchion, allowing the animal to stand or lie down. During the collection period, feces produced daily were measured as follows: feces left the chamber through openings on the floor in the back of the stanchion and were collected into tanks located underneath the floor of the chambers. Urine was collected through the use of the urine collection cup method of Fellner et al. (1988) modified to enable floor level urine collection. The $\mathrm{pH}$ of urine was maintained at $<3.5$ through the addition of adequate volumes of sulfuric acid $10 \%$ (vol/vol). During each of the 3 collection periods, urine and feces were weighed daily, sampled (5\% of the total weight) and pooled per cow. All of the samples were stored at $-20^{\circ} \mathrm{C}$. Before analysis, feces were oven dried at $55^{\circ} \mathrm{C}$ until constant weight and ground through a 1-mm screen. A fresh subsample was used for the $\mathrm{N}$ analysis.

Cows had free access to water and were offered feed twice daily at 0800 and $1700 \mathrm{~h}$; orts were recorded once daily and feeding rate adjusted to yield orts of approximately $10 \%$ of intake. Within each sample collection period, silages, TMR, and ort samples were sampled daily to obtain a composite sample and stored at $-20^{\circ} \mathrm{C}$. Weekly samples were also taken from alfalfa pellets, wheat straw, corn meal, solvent soybean meal, and concentrate mix. Samples were dried in a ventilated oven at $55^{\circ} \mathrm{C}$ for $48 \mathrm{~h}$. After drying, TMR, silages, and orts were ground through a 1-mm screen (Pulverisette 14; Fritsch GmbH, Markt Einersheim, Germany). 
Silages were also ground through a $2-\mathrm{mm}$ screen for the in situ procedure.

Silages, TMR, orts, and feces were analyzed for content of DM (method 945.15; AOAC, 1995); ash (method 942.05; AOAC, 1995); CP (method 984.13; AOAC, 1995); ether extract (method 920.29; AOAC 1995); starch (method 996.11; AOAC, 1998); NDF, corrected for insoluble ash and with the addition of $\alpha$-amylase (aNDFom; Mertens, 2002), and ADF (Van Soest et al., 1991), using the Ankom 200 fiber analyzer (Ankom Technology Corp., Fairport, NY); ADL (Van Soest, 1963); and gross energy, using an adiabatic bomb calorimeter (IKA 4000; IKA Werke GmbH \& Co. KG, Staufen, Germany). Silage samples were also analyzed for lactic acid, VFA, and ethanol (Fussell and Mc Calley, 1987), ammonium- $\mathrm{N}$ by direct distillation and titration using a Kjeltec 2300 analyzer (Foss Analytical A/S, Hillerød, Denmark), nitrogen bound to NDF and ADF (Licitra et al., 1996), and total ethanol-soluble carbohydrates (DuBois et al., 1956). Total mixed ration sample particle size was determined using the Penn State Particle Separator (Heinrichs and Kononoff, 2002).

Cows were milked twice daily, yield was recorded at each milking, and milk samples were collected daily ( $2 \%$ of total weight) with the addition of potassium dichromate as a preservative and stored at $4^{\circ} \mathrm{C}$ before analyses. Milk samples were pooled for cow and period and analyzed for total N (method 991.20; AOAC 1995) at the end of each experimental period. In addition, during each of the 2 milkings at d 3 and 5 , individual milk samples were collected and analyzed for protein, fat, lactose, and casein content using a Fourier transform infrared (FTIR) analyzer (MilkoScan FT6000; Foss Analytical A/S). Milk urea nitrogen content was determined by a differential $\mathrm{pH}$ technique (Luzzana and Giardino, 1999).

\section{In Situ Rumen NDF Degradability}

Fiber rumen degradability of the silages was determined with the in situ method according to the NRC (2001) model using 3 fistulated Italian Friesian dry cows fed a 75:25 forage:concentrate diet, on a DM basis. The forage was a grass hay and the diet had $12 \% \mathrm{CP}, 55 \%$ $\mathrm{NDF}$, and $1.30 \mathrm{Mcal}$ of $\mathrm{NE}_{\mathrm{L}} / \mathrm{kg}$ of DM. Samples (2-mm grind size) were weighed $(3.5 \mathrm{~g})$ in duplicate in polyester bags with a pore size of $53 \mu \mathrm{m}$ and placed in the rumen for 9 different times $(2,4,8,16,24,36,48,72$, and 168 h). The sample size-to-bag surface area was $14.5 \mathrm{mg} /$ $\mathrm{cm}^{2}$. Ruminal kinetic parameters were estimated, by nonlinear regression of SAS Institute (2001), according to the equation of McDonald (1981):

$$
\mathrm{D}(\%)=\mathrm{a}+\mathrm{b} \times\left(1-\mathrm{e}^{-\mathrm{k}_{\mathrm{d}} \times(\mathrm{t}-1)}\right),
$$

where D is the potential degradability, a is the readily degradable fraction, $\mathrm{b}$ is the potentially degradable fraction, $k_{d}$ is the rate of degradation of fraction $b, t(h)$ is the incubation time, and $\mathrm{l}(\mathrm{h})$ is the lag time of the degradation of fraction $b$.

Effective degradability (ED) was calculated with a $k_{\mathrm{p}}$ of $0.03 / \mathrm{h}$ as follows (McDonald, 1981):

$$
\operatorname{ED}(\%)=\mathrm{a}+\left[\mathrm{b} \times \mathrm{k}_{\mathrm{d}} /\left(\mathrm{k}_{\mathrm{d}}+\mathrm{k}_{\mathrm{p}}\right)\right] \times \mathrm{e}^{-\mathrm{kp} \times 1} .
$$

\section{In Vitro Protocol and Prediction of NDF Total-Tract Digestibility}

The forage samples pooled by period (CS, WPGS, and FS silages, alfalfa, and wheat straw) and the TMR samples, collected in each experimental period, were analyzed for in vitro aNDFom rumen digestibility using the Ankom Daisy ${ }^{\mathrm{II}}$ incubator (Ankom Technology Corp.) with 2 incubation times at 6 and 24 h. Samples (1-mm grind size) were weighed $(0.250 \mathrm{~g})$ in duplicate in Ankom F57 filter bags. Rumen fluid was collected from 3 fistulated Italian Friesian dry cows fed a 75:25 forage:concentrate diet, on a DM basis, as already mentioned. Two digestion jars were filled with prewarmed $\left(39^{\circ} \mathrm{C}\right)$ Marten and Barnes (1980) buffer solution and placed into the Daisy ${ }^{\mathrm{II}}$ incubator. Four hundred milliliters of filtered rumen fluid was introduced into each jar. Jars were divided vertically by using a perforated plastic separator; after $6 \mathrm{~h}$ of incubation, the jars were opened under $\mathrm{CO}_{2}$ flow; the bags on one side of the jars were quickly collected, and the jars were closed again. The remaining bags were removed after $24 \mathrm{~h}$ of incubation. The bags removed from the jars were rinsed thoroughly with cold tap water and immediately analyzed for aNDFom content using the Ankom200 fiber analyzer. Incubations were repeated twice.

The digestion rates of pdNDF of the forages were estimated on the basis of in vitro NDFD values, as reported by Van Amburgh et al. (2003). The indigestible fiber pools (iNDF) of the forages were calculated as 2.4 times ADL (Chandler et al., 1980). Diets and animal inputs (such as BW, DMI, and milk production, among others) were entered in CNCPS model version 6.1 (Tylutki et al., 2008). Forage chemical composition and pdNDF $k_{d}$ derived from in vitro analysis were also entered in the model; for the nonforage feeds, the library $\mathrm{k}_{\mathrm{d}}$ values were used. Rumen digestibility of the pdNDF was predicted by the model. The ttNDFD was estimated assuming that intestinal digestibility of the 
NDF amount escaping rumen digestion was $20 \%$, according to Sniffen et al. (1992). The predicted ttNDFD was compared with the in vivo data.

\section{Statistical Analysis}

Statistical analysis was carried out using the GLM procedure of SAS (SAS Institute, 2001). In vivo data were analyzed with the following model:

$$
\mathrm{Y}_{\mathrm{ijk}(\mathrm{t})}=\mu+\mathrm{S}_{\mathrm{i}}+\mathrm{A}_{\mathrm{ij}}+\mathrm{P}_{\mathrm{k}}+\mathrm{T}_{(\mathrm{t})}+\mathrm{e}_{\mathrm{ijk}},
$$

where $Y_{i j k(t)}$ is the dependent variable, $\mu$ is the overall mean, $S_{i}$ is the square effect $(i=1,2), A_{i j}$ is the animal effect within square $(\mathrm{j}=1,3), \mathrm{P}_{\mathrm{k}}$ is the period effect, $\mathrm{T}_{(\mathrm{t})}$ is the diet effect $(\mathrm{t}=1,3)$, and $\mathrm{e}_{\mathrm{ijk}}$ is the residual error.

In situ/in vitro data were analyzed with the following model:

$$
\mathrm{Y}_{\mathrm{ij}}=\mu+\mathrm{S}_{\mathrm{i}}+\operatorname{cow} / \mathrm{run}_{\mathrm{j}}+\mathrm{e}_{\mathrm{ij}},
$$

where $Y_{\mathrm{ij}}$ is the dependent variable; $\mu$ is the overall mean; $\mathrm{S}_{\mathrm{i}}$ is the silage effect; cow/ $\mathrm{run}_{\mathrm{j}}$ is the effect with $\mathrm{j}=1,3$ for in situ data and $\mathrm{j}=1,2$ for in vitro data; and $e_{i j}$ is the residual error.

Least squares means estimates are reported; separation of least squares means was conducted at $\alpha=0.05$ using the PDIFF option in the LSMEANS statement. For all statistical analyses, significance was declared at $P \leq 0.05$ and trends at $P \leq 0.10$.

\section{RESULTS AND DISCUSSION}

\section{Silage and Diet Chemical Composition}

Chemical composition of the experimental silages is reported in Table 1. Starch content was highest for CS, intermediate for WPGS silage, and lowest for FS silage. Fiber fractions had the opposite tendency: highest for FS silage, intermediate for WPGS silage, and lowest for CS. Forage sorghum ADL content was lower than the value reported by Aydin et al. (1999) for a non-BMR hybrid. The protein content was in the normal range (NRC, 2001) for the forages tested, with a slightly higher content for grain sorghum. Ash content was higher in FS. The ash content reported by NRC (2001) for FS silage (sudangrass) is $10.9 \%$ of DM and higher than a typical corn silage ( $4.3 \%$ of DM), thus decreasing the energy value of sorghum. The DM contents of sorghum silages were close to the value (25\%) normally recommended (Castle and Watson, 1973) for optimum fermentation, as confirmed by low $\mathrm{pH}$ values and good fermentation characteristics. The ratio of lactate:acetate indicated better fermentation for CS despite moderate ethanol content. In our study, the acetate content of grain sorghum was lower than the value reported by Miron et al. (2007) but higher than the value reported by Tabacco et al. (2009) for grain sorghum ensiled in the Po Plain. The aerobic stability of silages depends greatly on the concentration of acetic acid, which acts as inhibitor of the growth of spoilage organisms. Therefore, acetic acid increases the aerobic stability exponentially (Danner et al., 2003). The acetic content of the silages of our study was within the range suitable for good aerobic stability without affecting DMI negatively.

Considering the analysis of the experimental diets (Table 2), some differences from expected values were observed, particularly for aNDFom, starch, and ash contents in the FS diet throughout the experiment. The ash content of FS silage explained the lower $\mathrm{NE}_{\mathrm{L}}$ content of the FS diet in comparison with the other diets. Dietary CP content was significantly $(P=0.005)$ lower for the CS diet and the difference is explained by the higher $\mathrm{CP}$ of corn meal (10.2\% DM) in comparison with the $\mathrm{CP}$ content of the CS used in this experiment. This difference in $\mathrm{CP}$ content also is a consequence of the need to balance the diets for the MP, using the same ingredients.

Results of diet particle size distribution are reported in Table 3. Diet FS had a higher percentage retained on the screen of $19-\mathrm{mm}$ size and similar to the value reported by Dann et al. (2008) for a diet with $45 \%$ FS (on a DM basis). A large range in the percentage of diet retained on the screen of 19 -mm size (14.7 to $35.2 \%$ ) was reported by Oliver et al. (2004) for sorghum silage diets ( $40 \%$ of DM). Guidelines for TMR are 2 to $8 \%$ of the particles in the upper sieve and no more than $20 \%$ in the bottom pan (Heinrichs and Kononoff, 2002). The data observed in this study indicate an excessive chop length at harvest for FS.

\section{Milk Production}

Results of DMI and milk production are reported in Table 4. A linear trend was observed for an effect of DMI $(P=0.07)$, depending on the kind of silage. Particularly, the FS diet resulted in a lower DMI, probably due to the greater particle size, as described in other studies in dairy cows (Schwab et al., 2002; Krause and Combs, 2003). As a consequence, milk yield was lower for FS in comparison with the CS diet $(P=0.05)$. Previous studies (Aydin et al., 1999; Oliver et al., 2004) showed a decrease in DMI and milk production in cows fed conventional FS hybrids. The cows fed the WPGS diet provided intermediate results in terms of milk yield. Fat yield $(\mathrm{kg} / \mathrm{d})$ was numerically higher for the 
Table 1. Chemical composition of the experimental forages

\begin{tabular}{|c|c|c|c|}
\hline Component & Corn silage & $\begin{array}{l}\text { Whole plant grain } \\
\text { sorghum silage }\end{array}$ & $\begin{array}{c}\text { Forage sorghum } \\
\text { silage }\end{array}$ \\
\hline DM, \% & 34.1 & 29.0 & 31.8 \\
\hline $\mathrm{CP}, \%$ of $\mathrm{DM}$ & 8.7 & 12.3 & 10.5 \\
\hline Ash, \% of DM & 4.3 & 5.9 & 14.4 \\
\hline $\mathrm{EE}^{2} \%$ of DM & 3.6 & 3.1 & 1.8 \\
\hline aNDFom, ${ }^{1} \%$ of DM & 39.5 & 45.2 & 62.5 \\
\hline $\mathrm{ADF}, \%$ of $\mathrm{DM}$ & 23.5 & 29.5 & 46.4 \\
\hline ADL, $\%$ of DM & 2.9 & 4.8 & 5.4 \\
\hline NPN, $\%$ of total $\mathrm{N}$ & 64.4 & 56.1 & 47.6 \\
\hline $\mathrm{NH}_{3}, \%$ of total $\mathrm{N}$ & 8.6 & 10.4 & 11.3 \\
\hline NDIN, $\%$ of total $\mathrm{N}$ & 11.6 & 12.4 & 22.4 \\
\hline ADIN, $\%$ of total $\mathrm{N}$ & 10.5 & 12.0 & 11.3 \\
\hline Starch, \% of DM & 31.5 & 20.8 & 3.4 \\
\hline Sugar, \% of DM & 2.9 & 2.6 & 2.3 \\
\hline $\mathrm{pH}$ & 3.64 & 3.90 & 4.28 \\
\hline Lactate, $\%$ of DM & 5.46 & 4.97 & 4.10 \\
\hline Acetate, $\%$ of DM & 1.72 & 2.38 & 1.92 \\
\hline Propionate, $\%$ of DM & 0.13 & 0.39 & 1.14 \\
\hline Butyrate, $\%$ of DM & $\mathrm{ND}^{3}$ & ND & ND \\
\hline Ethanol, $\%$ of DM & 1.78 & 0.64 & 0.13 \\
\hline
\end{tabular}

WPGS than the FS diet, whereas CS was intermediate $(P=0.09)$.

Milk protein yield $(\mathrm{kg} / \mathrm{d})$ was lower for FS than CS and intermediate for the WPGS $\operatorname{diet}(P=0.05)$. Milk urea $\mathrm{N}$ was higher for the FS than the CS diet, in agreement with the results of Colombini et al. (2010) and Dann et al. (2008). Milk urea $\mathrm{N}$ is affected by several factors and, among these, dietary $\mathrm{CP}$ content (Broderick and Clayton, 1997) and fermentable energy of the diet (Oltner and Wiktorsson, 1983) are the most significant: lower-protein diets with rapidly fermentable carbohydrate content usually decrease the MUN content. In this study, the FS diet had a significantly higher CP content and a lower energy value than the CS diet. Moreover, the rumen starch digestion rate is usually higher in corn silage than in corn meal; Lanzas et al. (2007) reported a starch digestion rate $(/ \mathrm{h})$ of 0.25 for unprocessed corn silage (35\% of DM) and a rate of 0.15 for corn grain ground fine. In the present study, corn meal was added in higher proportion in the FS diet than in the CS diet; hence, it can be hypothesized that in the FS diet, less energy was available in the rumen to convert ammonia into microbial protein. The WPGS diet was again intermediate with no difference compared with the other 2 dietary treatments.

\section{Total-Tract Nutrient Digestibility}

Nutrient digestibility is reported in Table 5. Organic matter, aNDFom, ADF, starch, and energy digestibilities were greater for the FS diet than the WPGS and CS diets. Total-tract aNDFom digestibility of the WPGS diet (48.6\%) was higher than the value reported by other studies (Grant et al., 1995; Oliver et al., 2004) and not different from the CS diet. The higher aNDFom digestibility of the FS diet $(54.1 \%)$ is probably due to a higher retention time in the rumen rather than to a better quality of the forage fiber. This is confirmed by the theoretical dietary forage $\mathrm{k}_{\mathrm{p}}$ calculated according to Fox et al. (2004) based on the measurements registered during the experiment (BW, DMI, and diet characteristics, including the physically effective NDF): 0.049, 0.042 , and $0.035 / \mathrm{h}$ for CS, WPGS, and FS silages, respectively. The hypothesis that the higher ttNDFD of the FS diet is mainly due to the higher rumen retention rather than to a higher rumen fiber degradability is confirmed by the data obtained in situ and in vitro (Table 6), which did not show any difference in the rate of degradation or in the effective degradability of aNDFom among the 3 forages tested. Similarly, Aydin et al. (1999) indicated no difference in the $\mathrm{k}_{\mathrm{d}}$ of NDF among conventional sorghum, BMR sorghum, and corn silages. The aNDFom $\mathrm{k}_{\mathrm{d}}$ of FS $(0.032 / \mathrm{h})$ was similar to the value obtained for a BMR sorghum harvested in the Po Plain area in a study of Colombini et al. (2010) and higher than the value reported by Oliver et al. (2004) for conventional sorghum. A tendency $(P=0.08)$ existed for the potentially degradable fiber to be higher for CS than sorghum silages; this can be explained by the lower ratio ADL:NDF of CS (0.07) as compared with sorghum silages (0.11 and 0.09 for WPGS and FS silages, respectively). 
Table 2. Composition of the experimental diets (\% of DM, unless otherwise stated)

\begin{tabular}{|c|c|c|c|}
\hline \multirow[b]{2}{*}{ Composition } & \multicolumn{3}{|c|}{$\operatorname{Diet}^{1}$} \\
\hline & CS & WPGS & FS \\
\hline \multicolumn{4}{|l|}{ Ingredient } \\
\hline Corn silage & 41.5 & - & - \\
\hline Grain sorghum silage & - & 36.7 & - \\
\hline Forage sorghum silage & - & - & 28.0 \\
\hline Alfalfa pellets & 13.6 & 13.6 & 13.6 \\
\hline Wheat straw & 1.3 & 1.3 & 1.3 \\
\hline Corn meal & 16.0 & 21.3 & 29.4 \\
\hline Soybean meal solvent & 7.0 & 7.0 & 7.0 \\
\hline Concentrate $\operatorname{mix}^{2}$ & 17.8 & 17.8 & 17.8 \\
\hline Salt $^{3}$ & 2.6 & 2.6 & 2.6 \\
\hline Vitamin-mineral mix ${ }^{4}$ & 0.2 & 0.2 & 0.2 \\
\hline \multicolumn{4}{|l|}{ Chemical composition } \\
\hline $\mathrm{DM}, \%$ & 55.5 & 53.6 & 61.8 \\
\hline Ash & 7.1 & 7.8 & 9.7 \\
\hline $\mathrm{CP}$ & 16.0 & 17.0 & 16.8 \\
\hline $\mathrm{MP}^{5}$ & 10.9 & 10.9 & 11.0 \\
\hline $\mathrm{EE}^{6}$ & 4.2 & 4.3 & 4.2 \\
\hline aNDFom $^{7}$ & 36.6 & 35.8 & 37.0 \\
\hline $\mathrm{ADF}$ & 19.5 & 21.2 & 21.4 \\
\hline ADL & 3.6 & 3.8 & 3.5 \\
\hline Starch & 26.5 & 26.8 & 25.0 \\
\hline $\mathrm{NE}_{\mathrm{L}}{ }^{5}{ }^{5} \mathrm{Mcal} / \mathrm{kg}$ of $\mathrm{DM}$ & 1.71 & 1.68 & 1.63 \\
\hline
\end{tabular}

${ }^{1} \mathrm{CS}=$ corn silage diet; WPGS $=$ whole plant grain sorghum silage diet; FS = forage sorghum silage diet.

${ }^{2}$ Concentrate mix: $21 \%$ canola meal, $21 \%$ cotton seeds, $20 \%$ beet pulp, $19 \%$ barley meal, $8 \%$ soybean flakes, $8 \%$ sugar cane molasses, $2 \%$ urea $1 \%$ yeast.

${ }^{3}$ Salt: $30 \%$ sodium bicarbonate, $18 \%$ calcium carbonate, $18 \%$ potassium carbonate, $12 \%$ monocalcium phosphate, $9 \%$ potassium sulfate, $9 \%$ magnesium oxide, $4 \%$ sodium chloride.

${ }^{4}$ Provided (per kilogram): $17.5 \mathrm{mg}$ of $\mathrm{Zn}, 1.75 \mathrm{mg}$ of $\mathrm{Cu}, 0.75 \mathrm{mg}$ of Mn, $0.3 \mathrm{~g}$ of I, $0.13 \mathrm{~g}$ of Se, $0.02 \mathrm{~g}$ of Co, $1900 \mathrm{KIU}$ of vitamin A, 600 KIU of vitamin D, and 16,000 IU of vitamin $\mathrm{E}$.

${ }^{5}$ Calculated according to Cornell Net Carbohydrate and Protein System (CNCPS) version 5 .

${ }^{6}$ Ether extract.

${ }^{7} \mathrm{NDF}$, corrected for insoluble ash and with the addition of $\alpha$-amylase.

Total-tract starch digestibility was very high and it was slightly lower, yet significant, for the CS and WPGS diets than the FS diet $(P<0.01)$. To improve starch digestibility, processing of the grain is needed for all cereals to break the seed coat (Beauchemin et al., 1994), especially for corn and grain sorghum (Theurer et al., 1999). Taking this into account, a possible explanation that can be given is that a small proportion of the whole corn and sorghum grains was not broken by the on-board rollers during harvesting, resulting in an overall decrease in starch digestibility.

\section{Fiber Digestibility Prediction Based on In Vitro Results}

The in vitro NDFD at $24 \mathrm{~h}$ of in vitro incubation of TMR samples did not reveal $(P=0.14)$ any difference among the experimental diet values $(43.0,37.8$, and $44.7 \%$ for CS, WPGS, and FS diets, respectively), which were lower than the in vivo results (Table 5). However, the rank of the 3 diets in terms of $24 \mathrm{~h} \mathrm{ru}-$ men fiber digestibility was again in favor of FS followed by CS and, with the lowest value, WPGS. The values obtained were lower than those of the in vivo, partly because of the shorter time used for the in vitro analysis $(24 \mathrm{~h})$ similarly to the results reported by Di Marco et al. (2009).

Considering the estimation of the fiber $\mathrm{k}_{\mathrm{d}}$ of the 3 silages (Table 6$)$, no significant difference $(P=0.32)$ was registered between the in situ and the in vitro method. Using the in vitro $\mathrm{k}_{\mathrm{d}}$ values, the prediction of the rumen dietary NDFD was obtained by CNCPS model version 6.1 (Tylutki et al. 2008), whereas ttNDFD was estimated, as previously described, assuming that intestinal digestibility of the NDF amount escaping rumen digestion was 20\% (Sniffen et al. 1992). The estimated ttNDFD values were $37.7,36.3$, and $39.5 \%$ for the CS, WPGS, and FS diets, respectively. This prediction gave lower values (on average, $37.8 \%$ ) than those observed in vivo (on average, 51.4\%). It must be recognized that some critical aspects exist in the prediction model applied. In this regard, the underesti-

Table 3. Diet particle size distributions

\begin{tabular}{|c|c|c|c|c|c|c|}
\hline \multirow{3}{*}{$\begin{array}{l}\text { Particle size fraction, }{ }^{1} \% \\
\text { retained (as-fed basis) }\end{array}$} & \multicolumn{6}{|c|}{$\operatorname{Diet}^{2}$} \\
\hline & \multicolumn{2}{|c|}{ CS } & \multicolumn{2}{|c|}{ WPGS } & \multicolumn{2}{|c|}{ FS } \\
\hline & Mean $^{3}$ & $\mathrm{SD}$ & Mean & $\mathrm{SD}$ & Mean & $\mathrm{SD}$ \\
\hline$>19 \mathrm{~mm}$ & 1.5 & 0.4 & 4.8 & 2.2 & 18.5 & 3.2 \\
\hline$>8$ to $19 \mathrm{~mm}$ & 39.2 & 2.3 & 39.3 & 1.9 & 20.8 & 2.9 \\
\hline 1.18 to $8 \mathrm{~mm}$ & 33.9 & 1.6 & 28.5 & 1.8 & 30.0 & 0.9 \\
\hline$<1.18 \mathrm{~mm}$ & 25.4 & 3.9 & 27.4 & 2.7 & 30.8 & 2.7 \\
\hline
\end{tabular}

${ }^{1}$ Determined with the Penn State Particle Separator (Heinrichs and Kononoff, 2002).

${ }^{2} \mathrm{CS}=$ corn silage diet; WPGS = whole plant grain sorghum silage diet; FS = forage sorghum silage diet.

${ }^{3}$ Mean of 6 composite samples (1 per cow per period). 
Table 4. Dry matter intake and milk yield of the cows fed the experimental diets

\begin{tabular}{|c|c|c|c|c|c|}
\hline \multirow[b]{2}{*}{ Item } & \multicolumn{3}{|c|}{$\operatorname{Diet}^{1}$} & \multirow[b]{2}{*}{ SE } & \multirow[b]{2}{*}{$P$-value } \\
\hline & $\mathrm{CS}$ & WPGS & FS & & \\
\hline DMI, kg/d & 20.0 & 20.0 & 18.2 & 0.53 & 0.07 \\
\hline Milk yield, $\mathrm{kg} / \mathrm{d}$ & $25.4^{\mathrm{a}}$ & $24.6^{\mathrm{ab}}$ & $23.6^{\mathrm{b}}$ & 0.43 & 0.05 \\
\hline $4 \%$ FCM, kg/d & 25.6 & 25.8 & 24.1 & 0.48 & 0.07 \\
\hline $4 \% \mathrm{FCM} / \mathrm{DMI}$ & 1.28 & 1.29 & 1.32 & 0.03 & 0.63 \\
\hline Fat, $\%$ & 4.08 & 4.33 & 4.16 & 0.08 & 0.14 \\
\hline Fat yield, $\mathrm{kg} / \mathrm{d}$ & 1.03 & 1.06 & 0.98 & 0.02 & 0.09 \\
\hline Protein, $\%$ & 3.36 & 3.28 & 3.31 & 0.07 & 0.31 \\
\hline Protein yield, $\mathrm{kg} / \mathrm{d}$ & $0.85^{\mathrm{a}}$ & $0.81^{\mathrm{ab}}$ & $0.78^{\mathrm{b}}$ & 0.02 & 0.05 \\
\hline Casein, \% & 2.79 & 2.73 & 2.71 & 0.03 & 0.25 \\
\hline Casein, kg/d & $0.71^{\mathrm{a}}$ & $0.67^{\mathrm{ab}}$ & $0.64^{\mathrm{b}}$ & 0.02 & 0.05 \\
\hline Lactose, \% & 5.11 & 5.09 & 5.10 & 0.03 & 0.57 \\
\hline Lactose yield, $\mathrm{kg} / \mathrm{d}$ & $1.29^{\mathrm{a}}$ & $1.25^{\mathrm{ab}}$ & $1.19^{\mathrm{b}}$ & 0.02 & 0.05 \\
\hline MUN, $\mathrm{mg} / \mathrm{dL}$ & $10.7^{\mathrm{a}}$ & $11.9^{\mathrm{ab}}$ & $12.9^{\mathrm{b}}$ & 0.5 & 0.05 \\
\hline
\end{tabular}

$\overline{a, b}$ Least squares means within a row with different superscripts are different $(P<0.05)$.

${ }^{1} \mathrm{CS}=$ corn silage diet; WPGS $=$ whole plant grain sorghum silage diet; FS = forage sorghum silage diet.

mation of the predicted NDFD can be explained by an overestimation of the $\mathrm{k}_{\mathrm{p}}$. A recent meta-analysis study (Krizsan et al., 2010) showed that the $\mathrm{k}_{\mathrm{p}}$ values estimated from the rumen evacuation technique were lower than those predicted from the CNCPS according to Seo et al. (2006), based on studies with external markers. Furthermore, the $\mathrm{k}_{\mathrm{p}}$ values in the model are referred to the whole feed, and not to the single fractions, with a consequent great influence, particularly on fiber, due to its slower $k_{p}$ in comparison with the soluble and with the readily degradable fractions. The reticulo-rumen is a system with selective retention of feed particles; not considering this aspect leads to serious underestimation of NDF digestibility (Huhtanen et al., 2006).

Another questionable point is the assumption that indigestible NDF is equal to 2.4 times ADL for any feed. Raffrenato et al. (2008) showed that the ratio between ADL and iNDF is not constant. Particularly, it is higher in forages with high ADL and NDF and lower in most CS and grasses. A wrong evaluation of iNDF results in a bias in the predicted $\mathrm{k}_{\mathrm{d}}$ value. Particularly, an overestimation of iNDF determines an overestimation of the $\mathrm{k}_{\mathrm{d}}$, and vice versa. Moreover, in the present study the use of dry cows as donor animals might have affected the in vitro NDFD and, consequently, the $\mathrm{k}_{\mathrm{d}}$ values, as suggested by Ward (2009) who showed that the inoculum obtained from dry cows gave NDFD values lower (on average, $-10 \%$ ) than the values obtained using the inoculum from lactating cows. Furthermore, the forage-to-concentrate ratio of the diets fed to the donor animals can affect the in vitro results. Nagadi et al. (2000) showed that bacterial DM and gas production increased as the ratio of concentrate to hay increased in the donor sheep diets, suggesting a 60:40 hay-toconcentrate ratio in the donor animal diets (lower than that used in the present study: 75:25).

Finally, it is known that NDF actually is composed of several pools with different degradation rates (Mertens

Table 5. Total-tract digestibility (\%) of the experimental diets

\begin{tabular}{lccccc}
\hline & \multicolumn{5}{c}{ Diet $^{1}$} \\
\cline { 2 - 3 } Item & CS & WPGS & FS & SE & $P$-value \\
\hline OM & $70.4^{\mathrm{b}}$ & $69.5^{\mathrm{b}}$ & $71.7^{\mathrm{a}}$ & 0.51 & 0.05 \\
$\mathrm{CP}$ & 66.0 & $64.5^{2}$ & 66.3 & 1.43 & 0.66 \\
$\mathrm{EE}^{\mathrm{a}}$ & 75.5 & 75.7 & 78.0 & 0.51 & 0.60 \\
$\mathrm{aNDFm}^{3}$ & $51.4^{\mathrm{b}}$ & $48.6^{\mathrm{b}}$ & $54.1^{\mathrm{a}}$ & 0.94 & 0.01 \\
$\mathrm{ADF}$ & $37.8^{\mathrm{b}}$ & $40.4^{\mathrm{b}}$ & $44.7^{\mathrm{a}}$ & 1.67 & 0.05 \\
Starch & $97.3^{\mathrm{b}}$ & $96.6^{\mathrm{b}}$ & $98.1^{\mathrm{a}}$ & 0.23 & 0.01 \\
Energy & $68.6^{\mathrm{b}}$ & $67.7^{\mathrm{b}}$ & $70.2^{\mathrm{a}}$ & 0.470 & 0.01 \\
${ }^{\mathrm{a}, \mathrm{b}}$ Least squares means within a row with different superscripts are different $(P<0.05)$. & \\
${ }^{1} \mathrm{CS}=$ corn silage diet; WPGS $=$ whole plant grain sorghum silage diet; FS $=$ forage sorghum silage diet. \\
${ }^{2}$ Ether extract. \\
${ }^{3} \mathrm{NDF}$, corrected for insoluble ash and with the addition of $\alpha$-amylase.
\end{tabular}


Table 6. In situ and in vitro aNDFom rumen degradability of the experimental forages

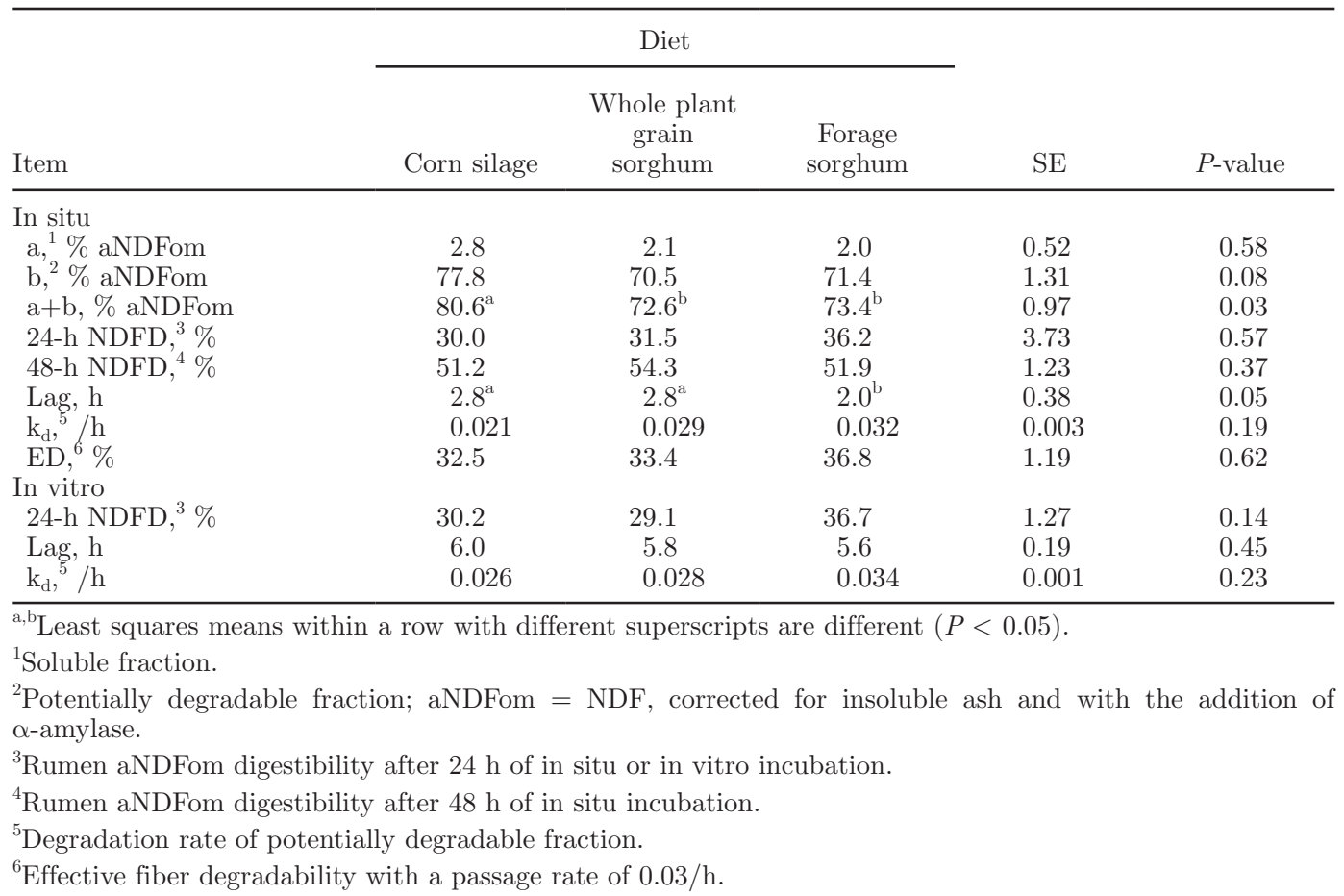

and Ely, 1982; Ellis et al., 2005; Huhtanen et al., 2008; Raffrenato et al., 2011). This was not considered in the current study, as the model used (Van Amburgh et al., 2003) predicts a $\mathrm{k}_{\mathrm{d}}$ for a single pool of potential digestible NDF assuming a first-order model (i.e., the $\mathrm{k}_{\mathrm{d}}$ is constant during fermentation) and a fixed iNDF.

\section{Nitrogen Utilization and Excretion}

Dietary effects on variables related to $\mathrm{N}$ utilization and excretion are reported in Table 7 . Nitrogen intake was not different among diets, as the higher $\mathrm{CP}$ content of the FS diet was offset by the lower DMI of this diet.

Table 7. Nitrogen balance of the cows fed the experimental diets

\begin{tabular}{|c|c|c|c|c|c|}
\hline \multirow[b]{2}{*}{ Item } & \multicolumn{3}{|c|}{$\operatorname{Diet}^{1}$} & \multirow[b]{2}{*}{$\mathrm{SE}$} & \multirow[b]{2}{*}{$P$-value } \\
\hline & CS & WPGS & FS & & \\
\hline $\mathrm{N}$ intake, $\mathrm{g} / \mathrm{d}$ & 513 & 542 & 493 & 16.2 & 0.17 \\
\hline \multicolumn{6}{|l|}{ Fecal excretion } \\
\hline $\mathrm{DM}, \mathrm{kg} / \mathrm{d}$ & 6.3 & 6.5 & 5.8 & 0.21 & 0.09 \\
\hline Total N, g/d & 174 & 191 & 166 & 7.09 & 0.08 \\
\hline Total N, \% of $\mathrm{N}$ intake & 34.0 & 35.5 & 33.7 & 1.43 & 0.66 \\
\hline \multicolumn{6}{|l|}{ Urinary excretion } \\
\hline Urine, $\mathrm{kg} / \mathrm{d}$ & 13.8 & 15.6 & 16.7 & 0.205 & 0.07 \\
\hline Total N, g/d & 138 & 157 & 158 & 6.14 & 0.10 \\
\hline Total N, \% of $\mathrm{N}$ intake & 27.5 & 29.3 & 31.8 & 1.17 & 0.08 \\
\hline \multicolumn{6}{|l|}{ Manure excretion } \\
\hline Total N, g/d & $313^{\mathrm{b}}$ & $348^{\mathrm{a}}$ & $323^{\mathrm{b}}$ & 6.59 & 0.01 \\
\hline Total N, \% of $\mathrm{N}$ intake & 61.5 & 64.8 & 65.5 & 1.45 & 0.18 \\
\hline \multicolumn{6}{|l|}{ Milk excretion } \\
\hline Total N, g/d & 133 & 126 & 122 & 3.47 & 0.13 \\
\hline $\mathrm{N}, \%$ of intake & 26.1 & 23.5 & 24.9 & 0.76 & 0.11 \\
\hline \multicolumn{6}{|l|}{$\mathrm{N}$ balance } \\
\hline $\mathrm{N}$ retained, $\mathrm{g} / \mathrm{d}$ & 66.9 & 66.8 & 47.5 & 11.7 & 0.43 \\
\hline $\mathrm{N}$ retained, $\%$ of $\mathrm{N}$ intake & 12.4 & 11.7 & 9.6 & 1.77 & 0.54 \\
\hline
\end{tabular}

$\overline{\mathrm{a}, \mathrm{b}}$ Least squares means within a row with different superscripts are different $(P<0.05)$.

${ }^{1} \mathrm{CS}=$ corn silage diet; WPGS $=$ whole plant grain sorghum silage diet; FS = forage sorghum silage diet. 
Feces produced were lower for cows fed the FS diet $(P=0.09)$ due to the lower DMI. A trend $(P=0.08)$ was observed for lower fecal $\mathrm{N}$ excretion $(\mathrm{g} / \mathrm{d})$ for the FS diet in comparison with the WPGS diet, but the $\mathrm{N}$ fecal excretion as a proportion of $\mathrm{N}$ intake was not different among diets.

The excretion of urine $(\mathrm{kg} / \mathrm{d})$ was lowest for CS, intermediate for WPGS, and highest for the FS diet $(P$ $=0.07)$. Dietary $\mathrm{CP}$ concentrations have been shown to affect urine excretion (Sannes et al., 2002; Broderick, 2003; Wattiaux and Karg, 2004) because a greater urine volume is required for excreting the excess $\mathrm{N}$ consumed by cows (Holter at al., 1982). Cows fed the FS diet, despite the numerically lowest $\mathrm{N}$ intake, had a urinary $\mathrm{N}$ excretion $(\mathrm{g} / \mathrm{d})$ similar to cows fed the WPGS diet in absolute value, and numerically higher as a percentage of $\mathrm{N}$ intake (29.3 vs. $31.8 \%$ for WPGS and FS, respectively), probably because of a less efficient $\mathrm{N}$ utilization at rumen level, with a consequent increase in the urine volume. The average urinary excretion was close to the value $(16.3 \mathrm{~kg} / \mathrm{d})$ reported by ASAE (2001) and lower than the average value $(24.1 \mathrm{~kg} / \mathrm{d})$ reported by Nennich et al. (2005) on the analysis of a wide data set; however, the average milk production of this latter data set (32.7 $\mathrm{kg} / \mathrm{d}$ ) was higher than the average value obtained in our study.

A trend occurred for a reduction of urinary $\mathrm{N}(\mathrm{g} / \mathrm{d})$ with the CS $\operatorname{diet}(P=0.10)$ in comparison with the other diets. Bacterial MP (\% total MP), estimated by CNCPS model version 6.1, was higher for the CS diet (54.4\%) than for the WPGS and FS diets $(48.4 \%$ for both), indicating a greater microbial protein synthesis at rumen level with the CS diet. As a consequence, urinary $\mathrm{N}$ excretion (\% $\mathrm{N}$ intake) was highest for $\mathrm{FS}$, intermediate for WPGS, and lowest for the CS diet $(P$ $=0.08$ ). The average urinary $\mathrm{N}$ excretion is lower than the percentage reported by Kebreab et al. (2010; 38\% of $\mathrm{N}$ intake) but similar to the value reported by Colmenero and Broderick (2006) for a diet with a $16.5 \%$ $\mathrm{CP}$ content on a DM basis.

Total $\mathrm{N}$ excretion (manure $\mathrm{N}, \mathrm{g} / \mathrm{d}$ ) was highest for the WPGS diet in comparison with the other diets $(P$ $=0.01$ ) and this difference is mainly due to the higher $\mathrm{N}$ intake of the WPGS diet; overall $\mathrm{N}$ manure excretion as a proportion of $\mathrm{N}$ intake was not different among diets and it was close to the average value reported by Kebreab et al. (2010) on a wide data set derived from in vivo experiments. $\mathrm{N}$ retention was similar in all dietary treatments and positive. The positive $\mathrm{N}$ balance is probably due to an overestimation of $\mathrm{N}$ retention, which, in turn, is consistent with the findings of Spanghero and Kowalski (1997) reported in a review of many nitrogen balance experiments on lactating cows. However, despite the possible little bias in terms of the absolute values, the rank of the 3 dietary treatments in terms of $\mathrm{N}$ utilization is valid.

\section{CONCLUSIONS}

With adequate starch supplementation, whole plant grain sorghum silage can replace corn silage in dairy cow TMR without any negative effect on milk production. Forage sorghum had NDFD comparable to the other silages; however, it was probably chopped too long, with a negative effect on DMI and milk production. In this experiment, the predicted ttNDFD values were lower than those in vivo. However, because several factors affect total-tract fiber digestibility and data in the literature are not always consistent, further investigation, particularly in vivo studies, are needed to better understand and predict ttNDFD.

\section{ACKNOWLEDGMENTS}

This research was supported by the Assessorato Agricoltura of the Regione Lombardia (Milan, Italy), project "Valutazione dei Foraggi Tradizionali e Alternativi e Sostenibilità delle Aziende Zootecniche Lombarde."

\section{REFERENCES}

American Society of Agriculture Engineers (ASAE). 2001. Manure production and characteristics. ASAE Standards D384.1. ASAE, St. Joseph, MI.

AOAC (Association of Official Analytical Chemists). 1995. Official Methods of Analysis. 15th ed. AOAC, Washington, DC.

AOAC (Association of Official Analytical Chemists). 1998. Official Methods of Analysis. 16th ed. Supplement 1998. AOAC, Washington, DC.

Aydin, G., R. J. Grant, and J. O'Rear. 1999. Brown midrib sorghum in diets for lactating dairy cows. J. Dairy Sci. 82:2127-2135.

Beauchemin, K. A., T. A. McAllister, Y. Dong, B. I. Farr, and K.-J. Cheng. 1994. Effects of mastication on digestion of whole cereal grains by cattle. J. Anim. Sci. 72:236-246.

Broderick, G. A. 2003. Effects of varying dietary protein and energy levels on the production of lactating dairy cows. J. Dairy Sci. 86:1370-1381.

Broderick, G. A., and M. K. Clayton. 1997. A statistical evaluation of animal and nutritional factors influencing concentrations of milk urea nitrogen. J. Dairy Sci. 80:2964-2971.

Castle, M. E., and J. N. Watson. 1973. The relationship between the DM content of herbage for silage making and effluents production. J. Br. Grassl. Soc. 28:135-138.

Chandler, J. A., W. J. Jewell, J. M. Gossett, P. J. Van Soest, and J. B. Robertson. 1980. Predicting methane fermentation biodegradability. Biotechnol. Bioeng. Symp. 10:93-107.

Colmenero, J. J. O., and G. A. Broderick. 2006. Effect of dietary crude protein concentration on milk production and nitrogen utilization in lactating dairy cows. J. Dairy Sci. 89:1704-1712.

Colombini, S., L. Rapetti, D. Colombo, G. Galassi, and G. M. Crovetto. 2010. Brown midrib forage sorghum silage for the dairy cow: Nutritive value and comparison with corn silage in the diet. Ital. J. Anim. Sci. 9:273-277.

Dann, H. M., R. J. Grant, K. W. Cotanch, E. D. Thomas, C. S. Ballard, and R. Rice. 2008. Comparison of brown midrib sorghum- 
sudangrass with corn silage on lactation performance and nutrient digestibility in Holstein dairy cows. J. Dairy Sci. 91:663-672.

Danner, H., M. Holzer, E. Mayrhuber, and R. Braun. 2003. Acetic acid increases stability of silage under aerobic conditions. Appl. Environ. Microbiol. 69:562-567.

Di Marco, O. N., M. A. Ressia, S. Arias, M. S. Aello, and M. Arzadún. 2009. Digestibility of forage silages from grain, sweet and bmr sorghum types: Comparison of in vivo, in situ and in vitro data. Anim. Feed Sci. Technol. 153:161-168.

DuBois, M., K. A. Giles, J. K. Hamilton, P. A. Rebers, and F. Smith. 1956. Colorimetric method of determination of sugars and related substances. Anal. Chem. 28:350-356.

Ellis, W. C., M. Mahlooji, and J. H. Matis. 2005. Models for estimating parameters of neutral detergent fiber digestion by ruminal microorganisms. J. Anim. Sci. 83:1591-1601.

European Commission. 1991. Directive of the Council of December 12 concerning the protection of waters against pollution caused by nitrates from agricultural sources (91/676/EEC). European Commission, Brussels, Belgium.

Fellner, V., M. F. Weiss, A. T. Belo, R. L. Belyea, F. A. Martz, and A. H. Orma. 1988. Urine cup for collection of urine from cows. J. Dairy Sci. 71:2250-2255.

Fox, D. G., L. O. Tedeschi, T. P. Tylutki, J. B. Russell, M. E. Van Amburgh, L. E. Chase, A. N. Pell, and T. R. Overton. 2004. The Cornell Net Carbohydrate and Protein System model for evaluating herd nutrition and nutrient excretion. Anim. Feed Sci. Technol. 112:29-78.

Fussell, R. J., and D. V. McCalley. 1987. Determination of volatile fatty acids (C2-C5) and lactic acid in silage by gas chromatography. Analyst (Lond.) 112:1213-1216.

Gardner, J. C., J. W. Maranville, and E. T. Paparozzi. 1994. Nitrogen use efficiency among diverse sorghum cultivars. Crop Sci. 34:728-733.

Grant, R. J., S. G. Haddad, K. J. Moore, and J. F. Pedersen. 1995. Brown midrib sorghum silage for midlactation dairy cows. J. Dairy Sci. 78:1970-1980.

Heinrichs, A. J., and P. J. Kononoff. 2002. Evaluating particle size of forages and TMRs using the New Penn State Forage Particle Separator. DAS 02-42. Cooperative Extension College Agric. Sci., Dept. Dairy and Animal Science, The Pennsylvania State University, University Park.

Holter, J. B., J. A. Byrne, and C. G. Schwab. 1982. Crude protein for high milk production. J. Dairy Sci. 65:1175-1188.

Huhtanen, P., S. Ahvenjärvi, M. R. Weisbjerg, and P. Nørgaard. 2006. Digestion and passage of fibre in ruminants. Pages 87-135 in Ruminant Physiology: Digestion, Metabolism and Impact of Nutrition in Gene Impression, Immunology and Stress. K. Sejrsen, T. Hvelplund, M. O. Nielsen, ed. Wageningen Academic Publishers, Wageningen, the Netherlands.

Huhtanen, P., A. Seppälä, S. Ahvenjärvi, and M. Rinne. 2008. Prediction of in vivo neutral detergent fiber digestibility and digestion rate of potentially digestible neutral detergent fiber: Comparison of models. J. Anim. Sci. 86:2657-2669.

Italian Ministry of Health. 1992. Protezione degli animali utilizzati a fini sperimentali o ad altri fini scientifici. D.Lgs 116/92. Gazzetta Ufficiale 40:5-25. (Rome, Italy).

Kebreab, E., A. B. Strathe, J. Dijkstra, J. A. N. Mills, C. K. Reynolds, L. A. Crompton, T. Yan, and J. France. 2010. Energy and protein interactions and their effect on nitrogen excretion in dairy cows. Pages 417-425 in Proc. 3rd Int. Symp. Energy Protein Metabol. Nutr. (EAAP publication no. 127). G. M. Crovetto, ed. Wageningen Academic Publishers, Wageningen, the Netherlands.

Krause, K. M., and D. K. Combs. 2003. Effects of forage particle size, forage source, and grain fermentability on performance and ruminal pH in midlactation cows. J. Dairy Sci. 86:1382-1397.

Krizsan, S. J., S. Ahvenjärvi, and P. Huhtanen. 2010. A meta-analysis of passage rate estimated by rumen evacuation with cattle and evaluation of passage rate prediction models. J. Dairy Sci. 93:5890-5901.

Lanzas, C., C. J. Sniffen, S. Seo, L. O. Tedeschi, and D. G. Fox. 2007. A revised CNCPS feed carbohydrate fractionation scheme for formulating rations for ruminants. Anim. Feed Sci. Technol 136:167-190.

Licitra, G., T. M. Hernandez, and P. J. Van Soest. 1996. Standardization of procedures for nitrogen fractionation of ruminant feeds. Anim. Feed Sci. Technol. 57:347-358.

Luzzana, M., and R. Giardino. 1999. Urea determination in milk by a differential $\mathrm{pH}$ technique. Lait 79:261-267.

Marten, G. C., and R. F. Barnes. 1980. Prediction of energy digestibility of forages with in vitro rumen fermentation and fungal enzyme systems. Pages 61-128 in Standardization of Analytical Methodology for Feeds. W. J. Pigden, C. C. Balch, and M. Graham, ed. Int. Dev. Res. Center, Ottawa, ON, Canada.

McDonald, I. 1981. A revised model for the estimation of protein degradability in the rumen. J. Agric. Sci. 96:251-252.

Mertens, D. R. 2002. Gravimetric determination of amylase-treated neutral detergent fiber in feeds using refluxing in beakers or crucibles: Collaborative study. J. AOAC Int. 85:1217-1240.

Mertens, D. R., and L. O. Ely. 1982. Relationship of rate and extent of digestion to forage utilization-A dynamic model evaluation. J. Anim. Sci. 54:895-905.

Miron, J., E. Zuckerman, G. Adin, R. Solomon, E. Shoshani, M. Nikbachat, E. Yosef, A. Zenou, Z. G. Weinberg, Y. Chen, I. Halachmi, and D. Ben-Ghedalia. 2007. Comparison of two forage sorghum varieties with corn and the effect of feeding their silages on eating behavior and lactation performance of dairy cows. Anim. Feed Sci. Technol. 139:23-39.

Nagadi, S., M. Herrero, and N. S. Jessop. 2000. The influence of diet of the donor animal on the initial bacterial concentration of ruminal fluid and in vitro gas production degradability parameters. Anim. Feed Sci. Technol. 87:231-239.

NRC. 2001. Nutrient Requirements of Dairy Cattle. 7th rev. ed. Natl Acad. Sci., Washington, DC.

Nennich, T. D., J. H. Harrison, L. M. VanWieringen, D. Meyer, A. J. Heinrichs, W. P. Weiss, N. R. St-Pierre, R. L. Kincaid, D. L. Davidson, and E. Block. 2005. Prediction of manure and nutrient excretion from dairy cattle. J. Dairy Sci. 88:3721-3733.

Oliver, A. L., R. J. Grant, J. F. Pedersen, and J. O'Rear. 2004. Comparison of brown midrib- 6 and -18 forage sorghum with conventional sorghum and corn silage in diets of lactating dairy cows. J. Dairy Sci. 87:637-644.

Oltner, R., and H. Wiktorsson. 1983. Urea concentrations in milk and blood as influenced by feeding varying amounts of protein and energy to dairy cows. Livest. Prod. Sci. 10:457-467.

Raffrenato, E., C. F. Nicholson, and M. E. Van Amburgh. 2011. A mathematical model to predict the size and rate of digestion of a fast and slow pool of NDF and the indigestible NDF. J. Dairy Sci. 94(E-Suppl. 1):455-456.

Raffrenato, E., M. E. Van Amburgh, and P. J. Van Soest. 2008. Measures of acid detergent lignin recovery and evaluations of the 2.4 time lignin factor for estimating indigestible NDF. J. Dairy Sci 91(E-Suppl. 1):420.

Sanderson, M. A. 1993. Aerobic stability and in vitro fiber digestibility of microbially inoculated corn and sorghum silages. J. Anim. Sci. 71:505-514.

Sannes, R. A., M. A. Messman, and D. B. Vagnoni. 2002. Form of rumen-degradable carbohydrate and nitrogen on microbial protein synthesis and protein efficiency of dairy cows. J. Dairy Sci. 85:900-908.

SAS Institute. 2001. User's Guide: Statistics. Release 8.01. SAS Inst. Inc., Cary, NC.

Schwab, E. C., R. D. Shaver, K. J. Shinners, J. G. Lauer, and J. G. Coors. 2002. Processing and chop length effects in brown-midrib corn silage on intake, digestion, and milk production by dairy cows. J. Dairy Sci. 85:613-623.

Seo, S., L. O. Tedeschi, C. Lanzas, C. G. Schwab, and D. G. Fox. 2006 Development and evaluation of empirical equations to predict feed passage rate in cattle. Anim. Feed Sci. Technol. 128:67-83.

Sniffen, C. J., J. D. O'Connor, P. J. Van Soest, D. G. Fox, and J. B. Russell. 1992. A net carbohydrate and protein system for evaluating cattle diets: II. Carbohydrate and protein availability. J. Anim. Sci. 70:3562-3577. 
Spanghero, M., and Z. M. Kowalski. 1997. Critical analysis of N balance experiments with lactating cows. Livest. Prod. Sci. 52:113122.

Spanghero, M., C. Zanfi, L. Rapetti, and S. Colombini. 2009. Impact of NDF degradability of corn silage on the milk yield potential of dairy cows. Ital. J. Anim. Sci. 8:211-220.

Tabacco, E., S. Piano, L. Cavallarin, T. F. Bernardes, and G. Borreani. 2009. Clostridia spore formation during aerobic deterioration of maize and sorghum silages as influenced by Lactobacillus buchneri and Lactobacillus plantarum inoculants. J. Appl. Microbiol. 107:1632-1641.

Theurer, C. B., J. T. Huber, A. Delgado-Elorduy, and R. Wanderley. 1999. Invited review: Summary of steam-flaking corn or sorghum grain for lactating dairy cows. J. Dairy Sci. 82:1950-1959.

Tylutki, T. P., D. G. Fox, V. M. Durbal, L. O. Tedeschi, J. B. Russell, M. E. Van Amburgh, T. R. Overton, L. E. Chase, and A. N. Pell. 2008. Cornell Net Carbohydrate and Protein System: A model for precision feeding of dairy cattle. Anim. Feed Sci. Technol. 143:174-202.
Van Amburgh, M. E., P. J. Van Soest, J. B. Robertson, and W. F. Knaus. 2003. Corn silage neutral detergent fiber: Refining a mathematical approach for in vitro rates of digestion. Pages 99-108 in Cornell Nutrition Conference Proceedings. Cornell University, Ithaca, NY

Van Soest, P. J. 1963. Use of detergents in the analysis of fibrous feeds. II. A rapid method for the determination of fiber and lignin. J. Assoc. Off. Anal. Chem. 46:829-835.

Van Soest, P. J., J. B. Robertson, and B. A. Lewis. 1991. Methods of dietary fiber, neutral detergent fiber and non-polysaccharides in relation to animal nutrition. J. Dairy Sci. 74:3583-3597.

Ward, R. 2009. Opportunities and challenges in determining forage digestibility values. J. Dairy Sci. 92(E-Suppl. 1):193. (Abstr.)

Wattiaux, M. A., and K. L. Karg. 2004. Protein level for alfalfa and corn silage-based diets: II. Nitrogen balance and manure characteristics. J. Dairy Sci. 87:3492-3502. 